\title{
The Authenticity of the James Ossuary
}

\author{
Amnon Rosenfeld ${ }^{1}$, Howard R. Feldman ${ }^{2,3}{ }^{*}$, Wolfgang E. Krumbein ${ }^{4}$ \\ ${ }^{1}$ Geological Survey of Israel (Emeritus), Jerusalem, Israel \\ ${ }^{2}$ Lander College for Women, The Anna Ruth and Mark Hasten School, A Division of Touro College, New York, \\ USA \\ ${ }^{3}$ Division of Paleontology, Invertebrates, American Museum of Natural History, New York, USA \\ ${ }^{4}$ Geomicrobiology, ICBM, Carl von Ossietzky Universitaet, Oldenburg, Germany \\ Email: ${ }^{*}$ feldspar4@optonline.net
}

Received 9 January 2014; revised 8 February 2014; accepted 15 February 2014

Copyright (C) 2014 by authors and Scientific Research Publishing Inc.

This work is licensed under the Creative Commons Attribution International License (CC BY).

http://creativecommons.org/licenses/by/4.0/

(c) (i) Open Access

\section{Abstract}

An archaeometric analysis of the James Ossuary inscription "James Son of Joseph Brother of Jesus" strengthens the contention that the ossuary and its engravings are authentic. The beige patina can be observed on the surface of the ossuary, continuing gradationally into the engraved inscription. Fine long striations made by the friction of falling roof rocks continuously crosscut the letters. Many dissolution pits are superimposed on several of the letters of the inscription. In addition to calcite and quartz, the patina contains the following minerals: apatite, whewellite and weddelite (calcium oxalate). These minerals result from the biogenic activity of microorganisms that require a long period of time to form a bio-patina. Moreover, the heterogeneous existence of wind-blown microfossils (nannofossils and foraminifers) and quartz within the patina of the ossuary, including the lettering zone, reinforces the authenticity of the inscription.

\section{Keywords}

James Ossuary; Archaeometric; Patina; Cretaceous; Nari; Geo-Microbiogenic; Microfossils

\section{Introduction}

An ossuary made of chalk and covered by beige to gray patina (Figure 1) was brought to the Geological Survey of Israel in August, 2002 in order to study its archaeometry. Lamaire [1] [2] noted that the following Aramaic inscription appears on one of the long outer walls of the ossuary:

= יעקב בר יוסף אחוי דישוע Ya'akob Son of Yoseph Brother of Yeshua (James Son of Joseph Brother of Jesus) Rosenfeld and Ilani [3] studied the archaeometry of the James Ossuary. They concluded that the patina indi-

${ }^{*}$ Corresponding author.

How to cite this paper: Rosenfeld, A., et al. (2014) The Authenticity of the James Ossuary. Open Journal of Geology, 4, 69-78. http://dx.doi.org/10.4236/ojg.2014.43007 


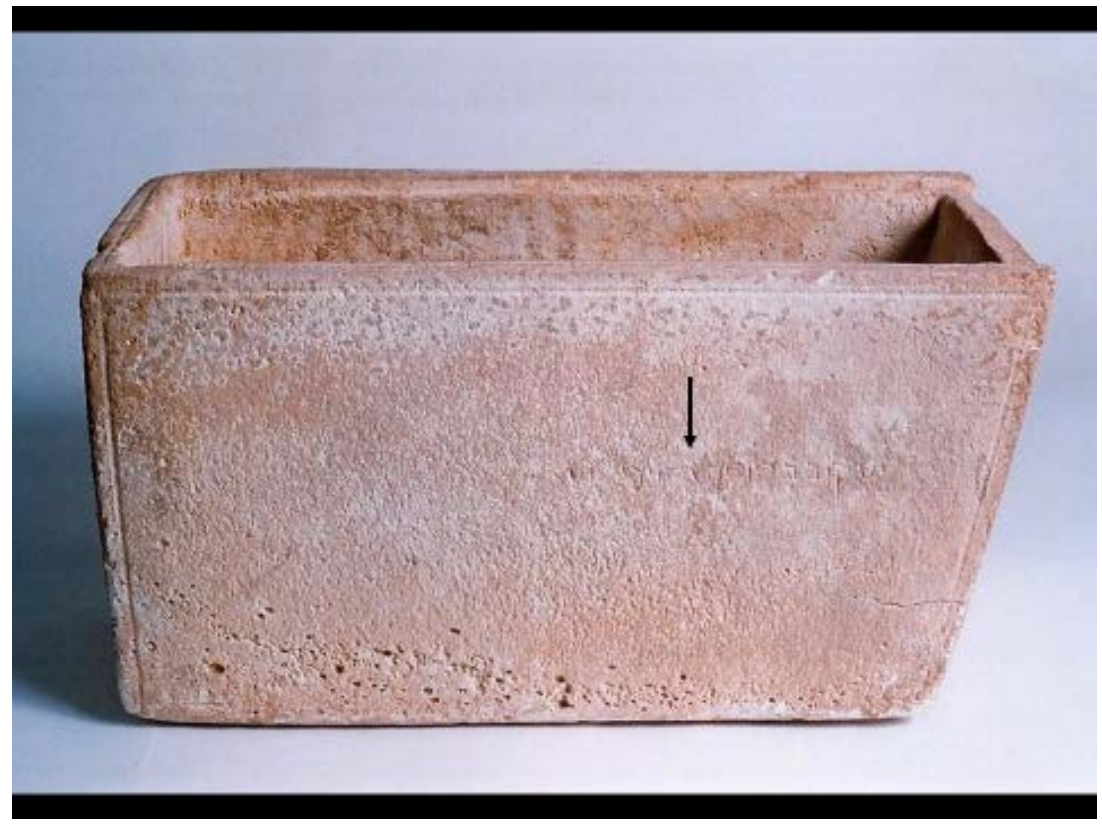

Figure 1. This illustrates the James Ossuary in 2002 before it was broken. Note the arrow pointing to the Aramaic inscription "Ya'akob Bar Yoseph Brother of Jesus." Note that the area around the inscription was cleaned. The (maximum) measurements of the ossuary are as follows: $56 \times 26 \times 30 \mathrm{~cm}$.

cates burial in a cave and that although the inscription was cleaned there was remnant patina found within some of the letters. Rosenfeld and Ilani [3] reported a high concentration of phosphorous (P) both within the stone and the patina.

Goren [4], in his report to the Israel Antiquities Authority (IAA) "Material Committee," concluded that the inscription was forged. But he also noted that the ossuary might have been cleaned.

A new method using oxygen isotopes to authenticate patinas in archaeological artifacts was described. Based on this technique, it was determined that the James Ossuary was a forgery [5] [6]. It was concluded that the forger prepared the patina of the James Ossuary artificially by applying powdered chalk immersed in boiling water over the freshly engraved inscription and that microfossils were found only in the inscription indicating additional evidence that the ossuary was forged. We would like to emphasize that in Israel $80 \%-90 \%$ of the archaeological artifacts are from unprovenanced origins and should definitely not to be overlooked. Archaeometric investigations should be carried out in order to authenticate important artifacts. This study deals with such an archaeometric analysis that is accompanied by a set of images supporting our contention that the inscription of the James Ossuary is authentic.

\section{Methods and Materials}

The mineralogical composition of the ossuary and patina was determined by using a petrographic microscope and a Philips X-ray diffractometer. Samples were removed from the ossuary and from the patina by peeling with a sharp steel blade. The samples were studied at the Geological survey of Israel [3]. A scanning electron microscope (SEM; JEOL-840), equipped with an energy dispersive spectrometer (EDS; Oxford-Link-Isis) was employed for a detailed inspection of the physical properties and structural features of the samples as well as for a chemical analysis. A Hitachi S-3200N SEM with low vacuum was used for further analyses of microorganism content within the patina layers. In addition, we used the ICBM electron microscopy unit at the Soil Science Department of Carl von Ossietzky Universität Oldenburg as well as the Institute of Crystallography of the Würzburg University for microscopy and X-ray diffractometric determination. The stone ossuary and the patina were examined by a magnifying lens and binocular microscope (magnification up to $\times 40$ ). The following samples were examined: remnants of the soil attached to the cavities found in the lower part of the outer sides of the ossuary, six samples of the chalk and six samples of the patina. 
The locations of the samples from the ossuary are as follows: samples 1 and 2 represent chalk of the ossuary, samples 3 and 4 represent brown patina; all four samples were taken from the fragment that was broken in the lower right corner of the inscription face; samples 5 and 6 are from the patina near the letters, sample 7 represents soil from the pits on the lower part of the ossuary (zone 1; see below for locations of the zones), sample 8 represents soil from the lower right corner of the inscription face, sample 9 is from the patina above the letter Samekh (of Yoseph) and samples 10 and 11 represent the original chalk from inside the ossuary.

\section{Archaeometric Analysis}

The archaeometric analysis includes structural features observed on the ossuary and within the inscription (Figures 1-8) as well as elemental content of the rock and the patina (including the inscription).

\subsection{Measurements}

The length of the ossuary is $50.5 \mathrm{~cm}$ at the base and flairs out to almost $56 \mathrm{~cm}$ at the top. When viewing the inscription one of the short sides is $100^{\circ}$ from the base and the other is slanted at $110^{\circ}$, giving the box a "trapezoidal shape." The maximum width of the ossuary is $26 \mathrm{~cm}$ and maximum height is $30 \mathrm{~cm}$. A flat lid, also made of chalk, rests on a small ledge $0.6 \mathrm{~cm}$ wide (Figure 1).

\subsection{External Features}

The long wall with the inscription on it contains dense oval solution cavities, or pits (Figures 1 and 2), that form three distinct zones from left to right that dip, or tilt, at an angle of about $20^{\circ}$. Pits are small depressions on the surface of a rock that form as a result of an erosive process as well as from bio-pitting. These processes take a long time (decades) to form according to Krumbein [7]. The lowermost zone (zone 1) extends about $13 \mathrm{~cm}$ in width and consists of large pits up to $10 \mathrm{~mm}$ in size and depth. Above is the middle zone (zone 2; Figures 2 and 3 )

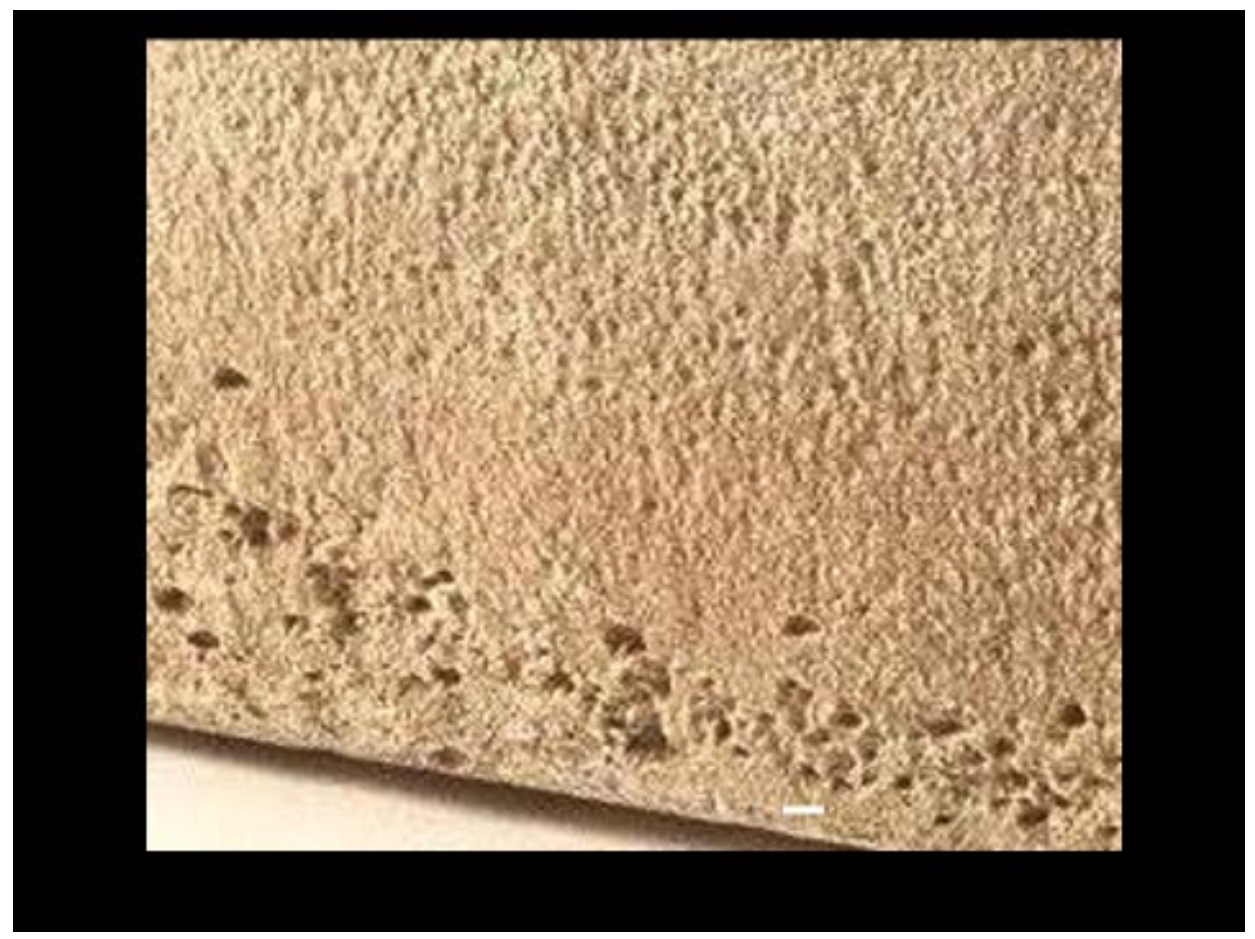

Figure 2. The lower section of the James Ossuary (the inscription face) showing the diagonal lower pitted zone (zone 1) with pits up to $10 \mathrm{~mm}$ in diameter and, the middle pitted zone (zone 2) just above it with pits up to $5 \mathrm{~mm}$ in diameter. Both pitted zones are characteristic of intensive weathering that is consistent with the diagenetic change from the chalky mother rock into Nari (caliche) (scale bar = $10 \mathrm{~mm}$ ). 


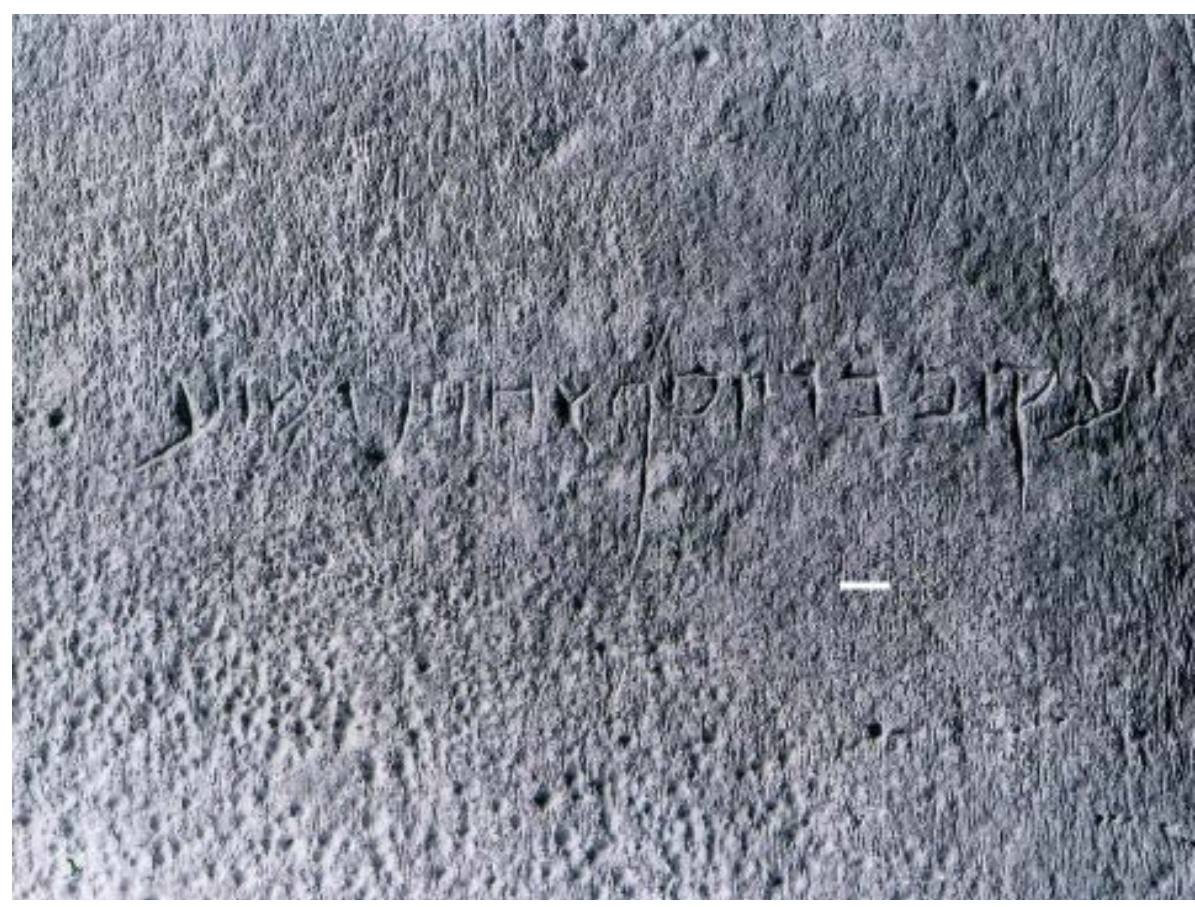

Figure 3. Note the vertical and diagonal striations on the surface of the ossuary that also crosscut the letters of the inscription. These ancient striations are probably from falling roof and wall rock and are due to natural causes such as weathering, earthquakes and floods during the 2000 years of storage in the cave (scale bar $=10 \mathrm{~mm}$ ).

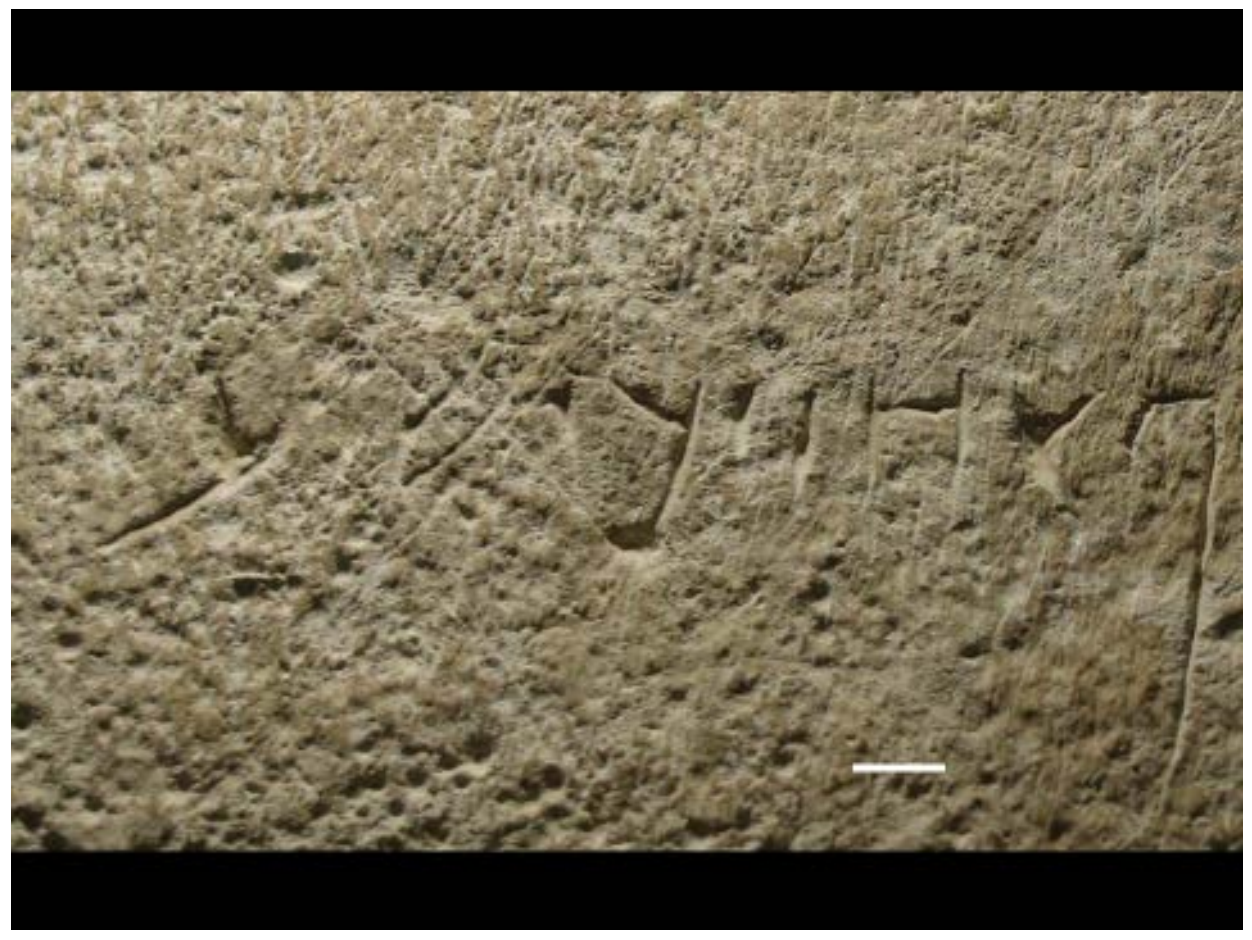

Figure 4. Note the dense oval solution cavities, or pits on the long wall on which is engraved the last part of the inscription "Akhuid'Yeshua” (before it was broken). Most of the striations crosscutting the letters are patinated. The pits are coated with the beige patina. The pits are distributed all over the ossuary as well as on the letters (e.g. "Aleph” "Yod," "Dalet," "Shin” and, "Ayin"; scale bar $=10 \mathrm{~mm}$ ). 


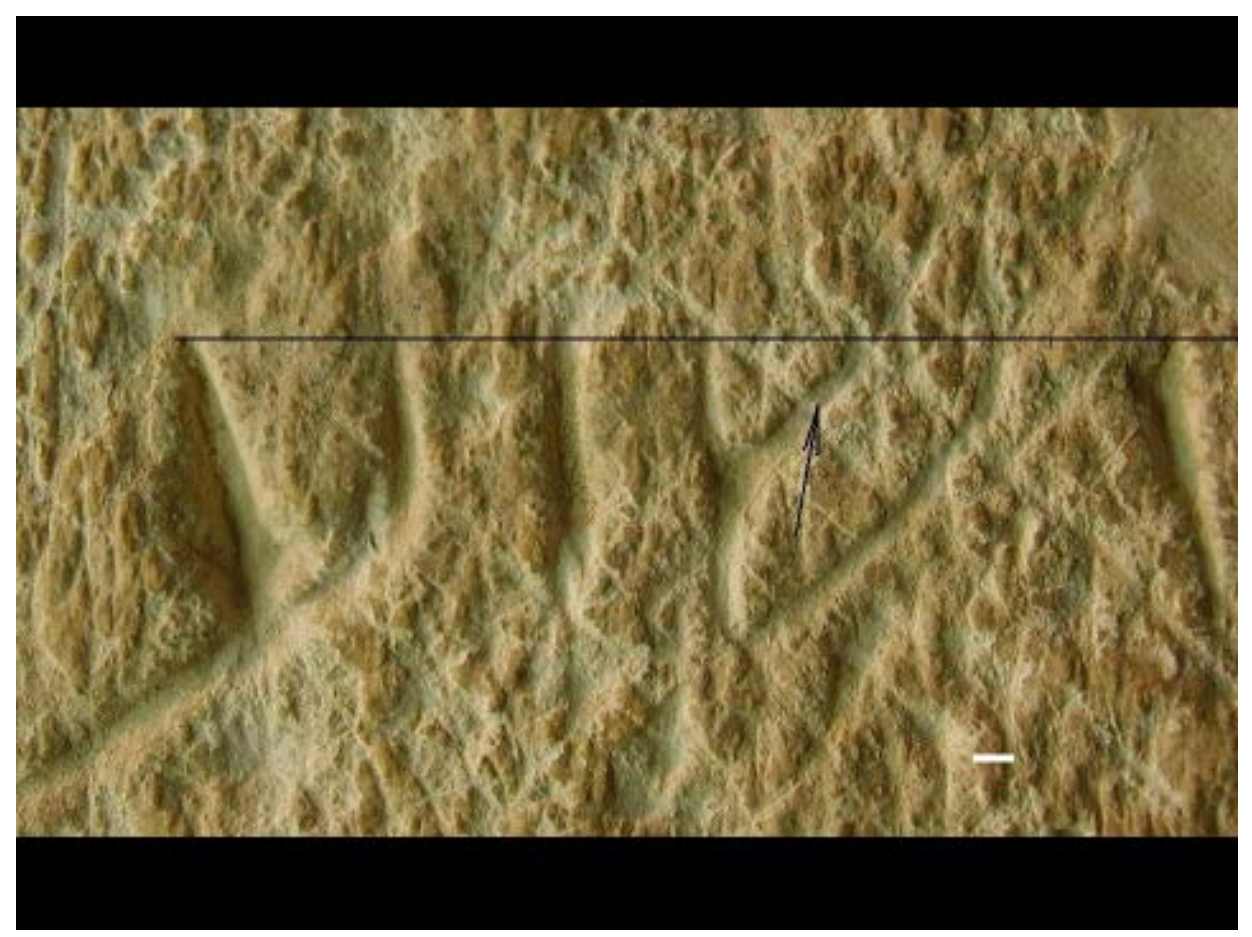

Figure 5. The engraved word Yeshua is illustrated above. Note the diagonal patinated striations on the surface of the ossuary that crosscut the letters of the inscription; e.g. the "Shin." These ancient striations are probably from falling roof stones as described above. The horizontal black line represents the top of the letters. The scribers of the first century CE used to engrave "hanging" letters from an upper line (scale bar $=1 \mathrm{~mm}$ ).

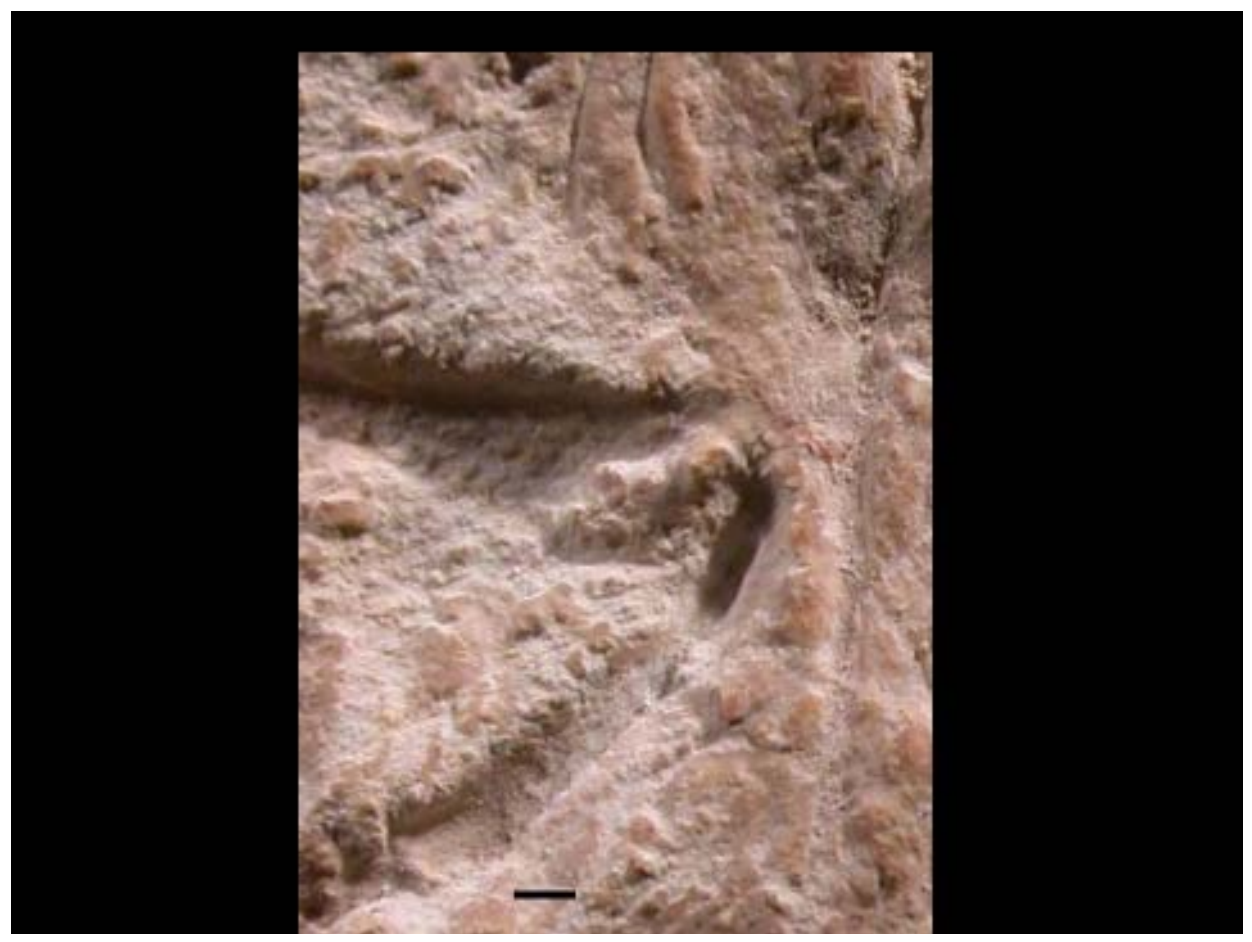

Figure 6. Note the partly cleaned engraved letter "Kuf" filled with the light gray patina as well as a coating of the beige patina above. This beige patina is continuous with and covers the surface of the ossuary, indicating the authenticity of the inscription (scale bar $=1 \mathrm{~mm}$ ). 


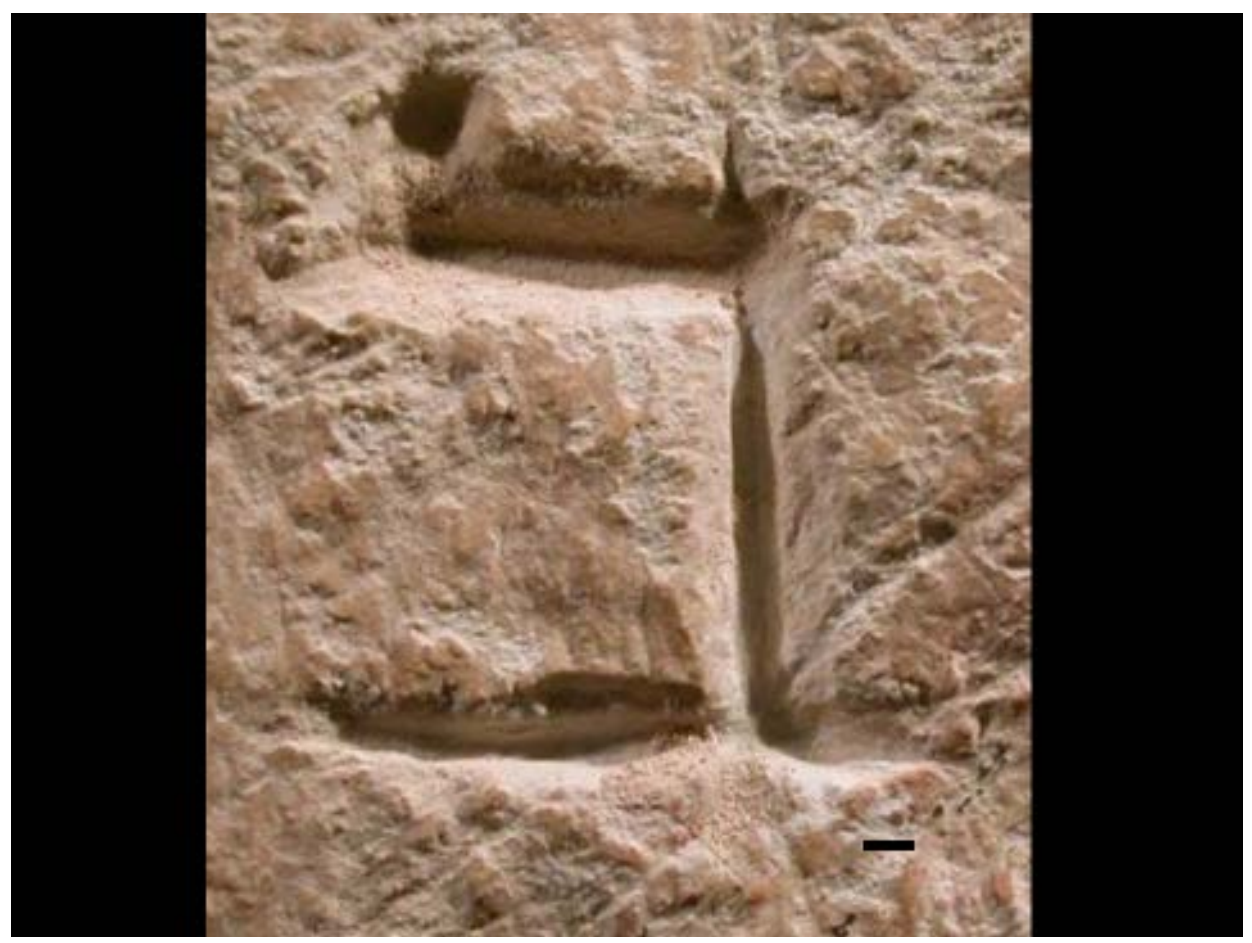

Figure 7. Note the beige light brown patina in the "Beth" of Ya'akob. The patina extends from the surface of the ossuary into the engraved letter but the engraving does not crosscut the patina. There are some striations on the surface of the ossuary that cross into the engraved letter from upper right to lower left (scale bar $=1 \mathrm{~mm}$ ).

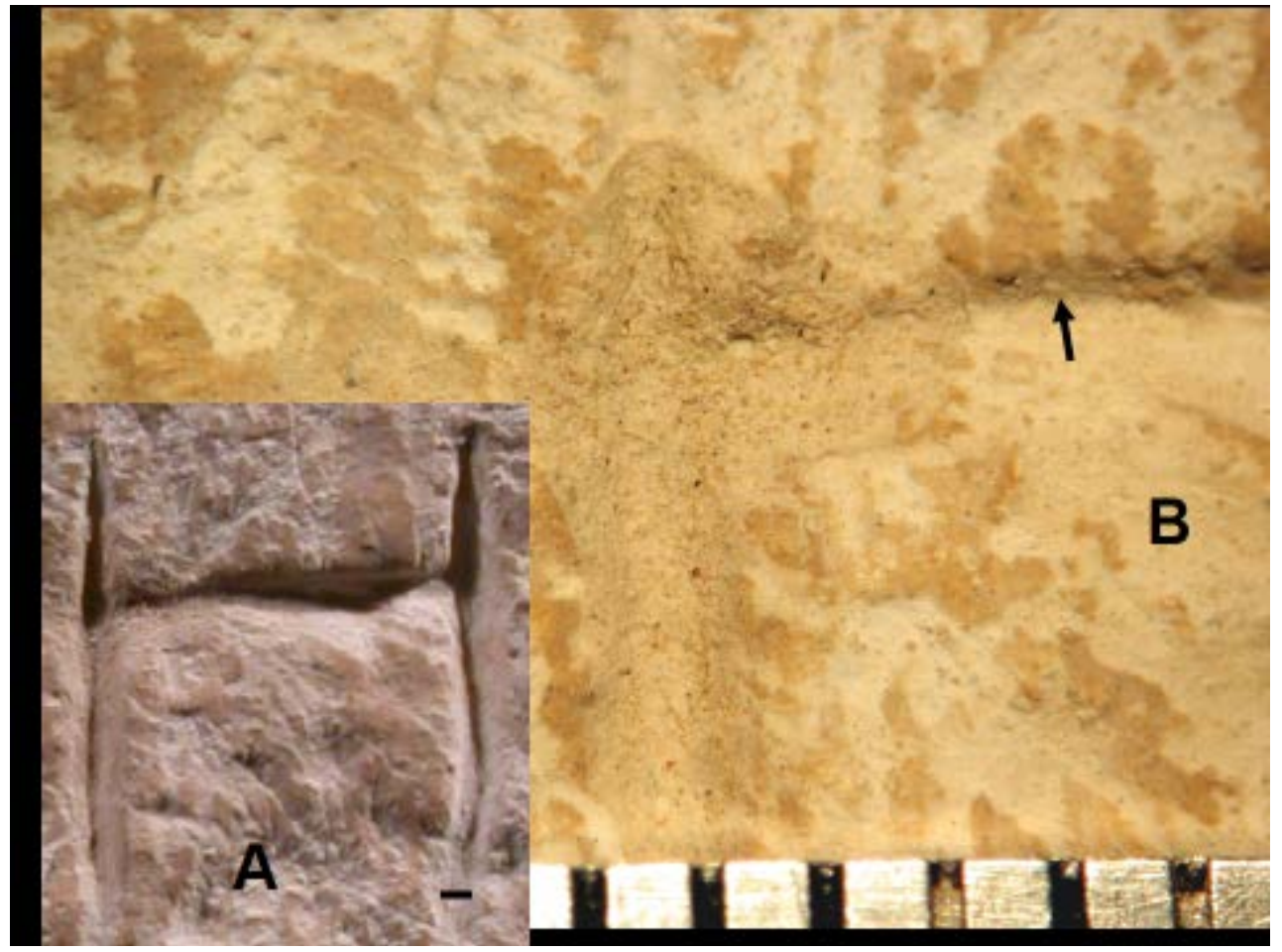

Figure 8. A. The "Het" of Akhui (scale bar $=1 \mathrm{~mm}$ ). B. Enlargement of the letter "Het" showing the real beige-brownish patina (arrow) on the left side of the upper stroke of the letter "Het." Left of it is the overlying fragmental remnants of an original cleaned patina. Scale bar in mm. 
that extends for another $12 \mathrm{~cm}$ in width and consists of numerous smaller pits about $2-5 \mathrm{~mm}$ in diameter. A third and uppermost zone (zone 3) (Figure 3) extends to the top of the ossuary and contains randomly scattered pits about $1-3 \mathrm{~mm}$ in diameter.

Thin striations, about $0.5 \mathrm{~mm}$ wide and up to several centimeters in length are found on the outer sides of the walls (Figure 3). These marks are mostly vertical, but there are also diagonal striations at an angle of $45^{\circ}$ (Figures 4 and 5). The striations were likely made by falling stones from the ceilings and walls of the cave probably induced by earthquakes and floods.

\subsection{Rock}

The Ossuary is made of chalk and was mined from the Cretaceous (Senonian) Menuha Formation in the lower Mount Scopus Group [8] [9]. This rock unit attains a thickness of up to $10 \mathrm{~m}$ in the Jerusalem area. The use of this chalk in Jerusalem was extensive during the Second Temple Period (2000 years BP) mainly for the manufacture of stone vessels and ossuaries [9]-[11]. The production of chalk vessels and Jewish ossuaries around Jerusalem during the $1^{\text {st }} \mathrm{BCE}$ and $1^{\text {st }} \mathrm{CE}$ centuries were related to the Jewish customs of purity.

The rock from which the ossuary was carved is not homogeneous; it was partially converted to a nari (caliche). Due to intensive weathering and the narization process the ossuary is extremely fragile. In fact, Keall [12] reported that the ossuary broke on its way from Israel to Toronto for exhibit at the Royal Ontario Museum (ROM). The lack of homogeneity of the rock can explain the fact that the letters seems to be engraved at different depths. Furthermore, it explains the "different hands" hypothesis suggested by some scholars.

\subsection{Patina}

The patina of an archaeological artifact is the outer weathered layer consisting mainly of the weathered source rock due to physical, chemical and biological (e.g. microorganism) factors. This resulted disintegration of the rock over time. Another component of the patina is the accretion of material from the environment and its interaction with soil and dust, including anthropogenic material, as well as water that sometimes deposits calcite. Patina rich in phosphate is typical of burial places where there is an abundant supply of bones. Thus, the patina is heterogeneous in nature.

In the James Ossuary we observed two layers of patina, a thin (film-like) beige layer above a white gray layer (Figure 6). The patina is up to $1 \mathrm{~mm}$ in thickness and discontinuous in places, suggesting episodic patina growth that was not developed continuously at a constant rate over a 2000 year period.

The beige patina can be found inside the letters, accreting gradationally into the inscription (Figures 7 and 8 ). The patina can be observed on the surface of the ossuary continuing into the engraving. The engraving clearly does not cut the patina. This phenomenon can be seen almost in every letter of the inscription despite cleaning with a sharp tool. The last letters of the inscription ("Yeshua") were not cleaned and the entire patina can be observed in these letters (Figures 4 and 5).

There are numerous fine striations crossing almost every letter (Figures 5 and 7). These striations were probably caused by falling roof rock in the cave during the past 2000 years. They occur on the surface of the ossuary, moving into the letters and are aligned in at least three sets dipping from upper left to lower right, upper right to lower left and vertically. Not only are the letters patinated but so are some of the striations. The striations can be seen in other letters of the inscription including the letters "Shin" and "Ayin" of the word "Yeshua" at the end of the inscription (Figure 5). The striations are filled with the same patina that is found on the surface of the ossuary and within the letters. This is another strong indication of authenticity.

Moreover, pits are also superimposed on the engraved letters (Figures 3-5). The following letters have superimposed pits: “Ayin”, “Kuf”, and "Beth” (Yaacov), “Resh” (Bar), “Samekh” (Yoseph),”Aleph” (Akhui), Dalet (two pits), "Shin" and "Ayin" (Yeshua). Likewise the letters with the pits on them are also partly patinated.

The fact that the striations occur at varying angles suggests that the ossuary shifted from its original horizontal position over the years and was at times partially submerged in water, indicated by the pitting. The lowermost zone (zone 1) was immersed for the longest time as evidenced by the larger pits in that zone.

In addition to calcium carbonate, the patina on the ossuary is also composed of the following minerals in descending volumetric order: apatite (calcium phosphate), whewellite (hydrated calcium oxalate), weddelite (calcium oxalate) and quartz (silicon dioxide) [7]. These minerals within the thin layers (films) of beige to gray patina are the product of geo-microbiogenic activity that covers all surfaces of the ossuary. The presence of mi- 
crocolonial fungi (MCF) forming circular pitted, embedded structures indicates slow growth over many years. These MCF structures and minerals were found on the surface of the ossuary and, more importantly, within the letters.

The inscription was cleaned [3] [4] [12] and the patina is therefore less prominent in several letters. The patina in several localities has numerous "cauliflower shapes" known to develop in a cave environment.

The so called "James Bond” faked patina (Figure 8) that was described by Goren [4] [13] as a "grainy” gray material is actually the same beige gray patina that covers the rest of the ossuary. This so-called fake patina (op. cit.) actually represents the chipped flakes of the original patina that were exfoliated by a cleaning process. It was observed by Goren [4] in only a few letters in the middle of the inscription (e.g. half of the "Het" and "Vav" of Yoseph; Figure 8) and was not found at the beginning or the end of the inscription. If a forger had done this we should have found this patina scattered all over the inscription rather than in a few recesses of some letters. We maintain the inscription was cleaned and Goren's [4] "grainy" patina is the remnant of the genuine cleaned patina.

The ossuary and its inscription were tested at the Royal Ontario Museum in 2002 with UV illumination and showed no suspicious glowing [14]. The result of this test is a strong indication for the authenticity of an inscription.

\subsection{Geochemistry}

Based on energy dispersive spectrometer (EDS) analysis of the scanning electron microscope (SEM) laboratory we found that the ossuary (rock) is composed mainly of $\mathrm{CaCO}_{3}(97 \%)$ and contains $\mathrm{Si}(1.5 \%), \mathrm{Al}(0.7 \%)$, Fe (0.4\%), P (0.3\%), and $\mathrm{Mg}(0.2 \%)$. The accreted patina shows similar composition, mainly $\mathrm{CaCO}_{3}(93 \%)$, and contains $\mathrm{Si}(5.0 \%), \mathrm{Al}(0.7 \%), \mathrm{P}(0.4 \%), \mathrm{Fe}(0.3 \%)$ and $\mathrm{Mg}(0.2 \%)$. The patina compared to the rock of the ossuary is enriched with silica and phosphate. The soil is composed mainly of $\mathrm{CaCO}_{3}(85 \%)$ and contains $\mathrm{Si}-7.4 \%$; $\mathrm{Al}-2.5 \%$; Fe-1.7\%; $\mathrm{P}-1.0 \%$, Ti-1.0\% and $\mathrm{Mg}-0.7 \%$. Note that there is a discrepancy between total amounts in the various samples due to the nature of EDS-SEM analysis. The patina does not contain any traces of modern tools and it adheres firmly to the stone.

\subsection{Dust}

Dust is an important component in soil and patina formation in the Middle East. Storm dust contributes about $50 \%$ of volume to the soil including minerals, microfossils and pollen. The patina of an artifact can have the same components, preserving its geological signature. The microfossil and mineral constituents in a patina could serve as a tool to authenticate unprovenanced artifacts [15] [16].

The James Ossuary (including its inscription) contains microfossils of marine origin. According to some workers [4] [6] the presence of microfossils is indicative of forgery. However, we found microfossils embedded within the entire patina, not only on the letters. Calcareous nannoplankton (about 5 - 10 microns) and foraminifers (about 100 - 200 microns) are elements that are commonly found in the dust of the Jerusalem area [7] [15] [16]. It is suggested that the microfossils were artificially deposited by grinding marine carbonate sediments and dissolving them in warm water [6]. This assumption was geochemically refuted [16]. The microfossils are not Recent, but range from Cretaceous to Tertiary in age, similar in age to the marine carbonate rocks that are widely exposed over most of Israel. The obvious source of this dust component is from mechanical erosion of the numerous outcrops of limestone and chalk in the region. In addition, the fact that the foraminifers are well preserved and have empty chambers (empty of sediment infilling) precludes the possibility that the patina was artificially deposited by the grinding of marine carbonate sediments as proposed by some [4] [6].

\subsection{Oxygen Isotopes}

Recently, the oxygen isotopic composition of the carbonate of the patina was analyzed and the results used to suggest that the James Ossuary was not authentic [5] [6]. This conclusion was based on the seven analyses of the patina. Six reported $\delta^{18} \mathrm{O}$ values are depleted relative to the expected stalagmite/stalactite range carbonate formation data ( $-4 \%$ o to $-6 \delta^{18} \mathrm{O} \%$ орDB $)[17]$.

However, Rosenfeld and Ilani [3] reported that the inscription was intensively cleaned chemically as well as by a sharp tool. Thus, the oxygen isotope results cannot be used to indicate a forgery because of suspected con- 
tamination. Moreover, patina growth on archaeological artifacts is completely different from natural speleothem growth of stalagmites with a constant water supply and stable temperature year round in a close cave [16] [18]. The formation of a patina on archaeological artifacts is produced in a few sporadic events in kinetic processes.

In addition, the compositions of oxygen isotopes were measured in patinas on 56 artifacts from officially sanctioned excavations and exhibit a wide range of values [19]. Thus, the patina on archaeological artifacts is not comparable to continuous growth of stalagmite rings. Therefore, the oxygen isotope measurements in patinas are not a reliable method for authentication of any archaeological artifact [16].

\section{Conclusions}

The results of our archaeometric analysis are as follows: 1) The natural beige patina can be found inside the letters of the James Ossuary accreting gradationally into the inscription; 2) Ancient patinated striations, likely caused by falling roof rocks in the cave, crosscut the surface of the ossuary and the letters of the inscription in the same direction; 3) Massive pitting, developed under atmospheric conditions after the engraving of the inscription on the ossuary, is also superimposed on several letters; 4) The presence of MCF forming circular pitted embedded structures and significant phosphate that is incorporated into the patina indicates slow growth over many years; 5) The patina does not contain any traces of modern tools and adheres firmly to the stone; 6) The cretaceous to tertiary microfossils found within the patina are similar in age to the marine carbonate rocks that are widely exposed over most of Israel and transported by dust storms; 7) Heterogeneous wind-blown microfossils and quartz are found within the patina of the ossuary, including the lettering zone.

\section{References}

[1] Lemaire M.A. (2002) Burial Box of James the Brother of Jesus-Earliest Archaeological Evidence of Jesus found in Jerusalem. Biblical Archaeology Review, 26, 24-33.

[2] Lemaire M.A. (2003) Ossuaire de Jacob/Jacque fils de Joseph, le frere de Jesus-Trois Inscriptions Arameennes sur Ossuaire et leur Interet. Comptes Rendus de L'Academie des Inscription \& Belles-Lettres, 301-319.

[3] Rosenfeld A. and Ilani S. (2002) SEM-EDS Analyses of Patina Samples from an Ossuary of Ya'akov Son of Yossef Brother of Yeshua. Biblical Archaeology Review, 28, 29.

[4] Goren Y. (2003) Examination of Authenticity: James Brother of Jesus Ossuary and Yehoash King of Yehuda Inscription. A Report in Israel Antiquities Authority. Bible and Interpretation. http://www.bibleinterp.com/articles/Goren_report.htm

[5] Ayalon A. (2003) Examination of Authenticity of the James Brother of Jesus Ossuary and Yehoash Inscription. A Report in Israel Antiquities Authority. Bible and Interpretation. http://www.bibleinterp.com/articles/Goren_report.htm

[6] Ayalon A., Bar-Matthews M. and Goren Y. (2004) Authenticity Examination of the Inscription on the Ossuary Attributed to James, Brother of Jesus. Journal of Archaeological Science, 31, 1189.

[7] Krumbein W. E. (2005) Preliminary Report: External Expert Opinion on Three Stone Items, n.p. Biblical Archaeology Review. Finds or Fakes, Biblical Archaeology. http://www.forananswer.org/Top_General/James_Ossuary_Report.pdf

[8] Flexer, A. (1964) Paleogeography of the Senonian and Maestrichtian in northern Israel. Unpublished Ph.D. Theses (in Hebrew; English Abstract), Hebrew University, Jerusalem, 157 p.

[9] Flexer A., Honigstein A., Rosenfeld A. and Polishook B. (1990) Geology, Geotechnical Properties and Exploitation of Chalk in Israel-An Overview. International Chalk symposium, Brighton, 1990, 63-70.

[10] Magen Y. (1984) Jerusalem as the Center for Stone-Ware Production during Herodian Times. Qadmoniot, 17, $124-127$.

[11] Magen Y. (2002) The Stone Vessel Industry in the Second Temple Period-Excavations at Hizma and the Jerusalem Temple Mount. In: Levana, T., Ed., Israel Exploration Society and Staff Officer of Archaeology, Old City Press Ltd., Jerusalem, 1-186.

[12] Keall E. J. (2003) New Tests Bolster Case for Authenticity. Biblical Archaeology Review, 26, 52-55.

[13] Silberman N. A. and Goren Y. (2003) Faking Biblical History. Archaeology, 56, 20-29.

[14] Newman R. (1990) Weathering Layers and the Authentification of Marble Objects. The Journal of the Paul Getty Museum, 263-282.

[15] Ganor E., Kronfeld J., Feldman H. R., Rosenfeld A. and Ilani S. (2009) Environmental Dust as a Tool to Study the Archaeometry of Patinas on Ancient Artifacts. Journal of Arid Environments, 73, 1170-1176.

[16] Kronfeld J., Rosenfeld A. and Feldman H. R. (2013) Determining the Authenticity of Artifacts by Oxygen Isotope 
Analysis. Open Journal of Geology, 23, 313-321. http://dx.doi.org/10.4236/ojg.2013.34036

[17] Bar-Matthews M. and Ayalon A. (1997) Late Quaternary Paleoclimate in the Eastern Mediterranean Region from Stable Isotope Analysis of Speleothems at Soreq Cave, Israel. Quaternary Research, 47, 155-168. http://dx.doi.org/10.1006/qres.1997.1883

[18] Rosenfeld, A., Feldman H. R. and Krumbein W. E. (2013) On the Authenticity of the James Ossuary and Its Possible Link to the Jesus Family Tomb. Proceedings of the 3rd Princeton Symposium on Judaism and Christian Origins, Jewish Views of the After Life and Burial Practices in Second Temple Judaism, Evaluating the Talpiot Tomb in Context, Jerusalem, 13-16 January 2008, 334-352.

[19] Shemesh, A. (2007) A Report on the Composition of Oxygen Isotopes of Patinas in Archaeological Artifacts as an Indicator for Authenticity. Environmental Sciences, Weitzman Institute for Science, Rehovot. 